\title{
MAKNA NAMA BUNGa dalaM KONSTRUKSI NAMA ORANG PADA MasYarakat KUTOARJO-JaWA tengah
}

\author{
KRISTOPHORUS DIVINANTO ADI YUDONO \\ Universitas Sanata Dharma \\ kristophorus3@gmail.com
}

\begin{abstract}
ABSTRAK
Penelitian bertujuan untuk, 1) mendeskripsikan salah satu wujud kearifan lokal yang ada pada masyarakat Kutoarjo, 2) mendeskripsikan nilai kearifan lokal, 3) mendeskripsikan makna nama bunga dan penyematan nama bunga dalam konstruksi penaman orang di masyarakat Kutoarjo, dan 4) mengetahui strategi preservasi agar pemberian nama bunga dalam konstruksi penamaan orang di masyarakat Kutoarjo tetap berlangsung secara turun temurun. Penelitian ini merupakan penelitian kualitatif etnografi yang dilakukan dengan pendekatan ekolinguistik alamiah. Sumber data dalam penelitian ini adalah 7 narasumber, yang terdiri dari pasangan suami istri yang menamai anaknya dengan menyisipkan nama bunga, serta seorang ibu dan pemuda yang memiliki nama bunga di dalam konstruksi namanya. Metode pengumpulan data dilakukan dengan wawancara. Teknik analisis data yang digunakan adalah analisis deskriptif meliputi reduksi data, penyajian data, dan penarikan kesimpulan. Hasil penelitian menunjukkan wujud kearifan lokal masyarakat Kutoarjo adalah adat yang istiadat yang berupa penyematan nama bunga pada konstruksi penamaan orang. Makna dari pemberian nama bunga pada konstruksi penamaan orang bagi masyarakat Jawa adalah sebagai doa, penyampaian harapan, dan kontrol sosial bagi anak dalam menjalani kehidupan. Nilai kearifan lokal dalam penyematan nama bunga dalam konstruksi penamaan orang adalah nilai pendidikan. Strategi preservasi yang dapat dilakukan antara lain mewariskan makna nama bunga dalam penamaan kepada anak, mengintegrasikan ke dalam pembelajaran di sekolah, dan mengemas dalam ensiklopedi nama bunga yang dapat digunakan dalam penamaan orang di masyarakat Jawa.
\end{abstract}

Kata kunci: nama, bunga, ekolinguistik

\section{PENDAHULUAN}

Indonesia merupakan salah satu negara di dunia yang memiliki kekayaan alam yang beragam. Setiap daerah di Indonesia memiliki kekayaan alam yang beragam terkait flora dan fauna. Beberapa fauna di Indonesia menjadi ciri khas Indonesia karena tidak ditemukan di negara lain. Sebagai contoh fauna yang menjadi ciri khas Indonesia adalah burung Cendrawasih yang berasal dari Papua. Selain fauna, keberagaman flora yang tersebar di seluruh negeri menjadi kekayaan tersendiri bagi Indonesia. Data badan Perencanaan Pembangunan Nasional BAPPENAS (2014) tumbuhan di Indonesia diperkirakan memiliki 25\% dari spesies tumbuhan berbunga yang ada di dunia. Indonesia menjadi merupakan urutan negara terbesar ketujuh dengan jumlah spesies mencapai 20.000 spesies dan $40 \%$ merupakan tumbuhan endemik atau asli Indonesia.

Kekayaan flora di Indonesia bukan hanya berkaitan dengan jenis, fungsi, bentuk, warna, tempat pertumbuhan belaka, melainkan kekayaan nama dari flora tersebut. Dynash (2013) mengungkapkan bahwa pemberian nama pada tumbuhan disebut nomenklatur. Proses pemberian nama tumbuhan melibatkan asas-asas yang diatur oleh peraturan-peraturan yang dibuat dan disahkan Kongres Botani Sedunia. Peraturan-peraturan tersebut secara formal dimuat pada Kode Internasional Tatanama Tumbuhan atau International Code of Botanical Nomenclature. Setiap flora memiliki kaidah penamaannya masing-masing, termasuk salah satu jenis flora yakni tanaman bunga. Nomenklatur bunga seperti, bunga Kusuma atau sering dikenal dengan bunga Wijayakusuma (Epiphyllum anguliger), bunga Widuri (Calotropis gigantea), atau bunga Cempaka (Magnolia champaca) telah disusun secara sistematis terkait penamaan dalam bahasa latin. Namun, terdapat fleksibilitas penamaan bunga pada setiap daerah di Indonesia. Hariyani (2013) mengungkapkan penamaan bunga di Indonesia disesuaikan oleh masing-masing daerah. Penamaan bunga yang berbeda di setiap daerah bergantung pada interpretasi atau pemaknaan masyarakat setempat terhadap bunga tersebut. Penamaan bunga di setiap daerah pun dapat disesuaikan dengan fungsi dari bunga tersebut dalam kehidupan sehari-hari. Setiap masyarakat memiliki kebebasan dalam menyikapi nama-nama tanaman yang ada di sekitar mereka, salah satunya adalah menyematkan di dalam sebuah nama lengkap. Masyarakat Jawa merupakan kelompok masyarakat yang menggunakan nama bunga untuk dimasukkan ke dalam konstruksi pemberian nama. 
Masyarakat Jawa dikenal memiliki keunikan dalam pemberian nama. Suranto (1983) mengungkapkan bahwa pemberian nama orang Jawa lahir berdasarkan cara masyarakat Jawa melakukan dialog dengan alam semesta dan lingkungan sosialnya melalui bahasa, perilaku, dan ide yang dilakukan dari masa ke masa. Salah satu kebiasaan pemberian nama di masyarakat Jawa yakni dengan menyisipkan nama bunga dalam konstruksi penamaan seseorang. Hal tersebut diungkapkan juga oleh Lono Simantupang dalam artikelnya dalam Harian Kompas yang berjudul "Nama Anak - Aristokratisme dan Keberatan Nama" di tahun 2006. Dalam artikelnya, Lono mengungkapkan bahwa pemberian nama-nama yang berkaitan dengan aspek alam, lingkungan sekitar, tumbuh-tumbuhan, hewan, menjadi sebuah kewajaran. Lono mengungkapkan bahwa pemberian nama pada masyarakat Jawa mencakup pada nama-nama yang berkaitan dengan ajaran agama, nama unsur kehidupan, nama tanaman serta hewan. Berdasarkan studi kepustakaan menurut Suranto (1983) dan Lono (2006), kedua artikel memiliki satu persamaan yakni masyarakat Jawa memiliki kebiasaan dalam menyisipkan nama bunga dalam konstruksi penamaan seseorang. Suranto (1983) menambahkan, masyarakat Jawa memiliki kepercayaan bahwa setiap bunga diyakini memiliki makna yang membuatnya menarik atau layak untuk disematkan dalam nama seseorang. Salah satu daerah yang masih menyisipkan nama bunga sebagai penamaan orang yakni daerah Kutoarjo. Namun tidak menutup kemungkinan daerah lain yang merupakan bagian dari suku masyarakat Jawa masih memiliki atau memberikan nama orang dengan menyisipkan nama bunga di dalamnya. Pemaknaan namanama bunga dalam konstruksi nama di kultur Jawa dapat diketahui melalui sudut pandang ekolinguistik.

Kajian ekolinguistik merupakan kajian ekologi bahasa yang menjadi paradigma baru yang berkaitan dengan hubungan ekologi dan linguistik. Ekolinguistik diprakarsai oleh Einar Haugen pada tahun 1970. Haugen (1972) berpendapat bahwa kajian bahasa dengan ekologi menjadi sebuah kajian atas interaksi bahasa dengan lingkungannya atau lingkungan tempat keberadaan bahasa itu digunakan. Pengertian ini sejalan dengan fenomena pemberian nama bunga pada kontruksi nama orang Jawa, yakni terjalin interaksi antara bunga / flora yang menjadi bagian dari lingkungan dan pemberian nama bunga, yang menjadi wujud bahasa, dan tidak terlepas dari faktor lingkungan tempat bahasa tersebut digunakan. Penggunaan nama bunga dalam kultur masyarakat Jawa tidak terlepas dari budaya turun-temurun yang tidak dapat diketahui secara pasti titik awal dimulainya budaya tersebut. Hal ini menunjukkan adanya keterkaitan antara bahasa dan budaya. Keterkaitan antara bahasa dan budaya diungkapkan Hariyono (1996) bahwa bahasa berfungsi sebagai sarana penting pewarisan, penurunan, pengembangan, dan penyebarluasan budaya. Hal tersebut dibuktikan hingga dewasa ini masih ditemukan pada masyarakat Jawa yang menyisipkan nama bunga dalam konstruksi penamaan orang di suku Jawa.

Perkembangan interdisiplin ilmu ekolinguistik lambat laun berfokus menjadi dua kategori. Stibbe (2015) menyebutkan bahwa pengertian ekolinguistik diartikan ke dalam dua pengertian, pengertian alamiah (natural ecolinguistics) dan pengertian metaforis (metaphoric ecolinguistics). Ekolinguistik metaforis berfokus pada interaksi bahasa dengan unsur sosial-budaya, sedangkan ekolinguistik alamiah berfokus pada interaksi, serta penggalian makna antara bahasa dengan flora fauna. Makna disebutkan oleh Odgen dan Richard (dalam Leech, 1974) sebagai hubungan antara kata, konsep, atau gagasan, dengan objek rujukan. Makna dari masing-masing bunga yang menjadi kearifan lokal masyarakat setempat, dikategorikan ke dalam jenis-jenis makna menurut Leech. Kategori makna nama bunga sebagai penamaan di masyarakat Jawa, dapat diketahui dengan melakukan pendataan terhadap makna-makna setiap bunga, yang diintepretasi oleh masyarakat dan menjadi sebuah kearifan lokal tersendiri bagi suku Jawa, khususnya masyarakat Jawa Tengah di kecamatan Kutoarjo.

Setiap wilayah di berbagai belahan dunia memiliki kearifan lokal. Hadayati (2016) mengartikan kearifan lokal sebagai tatanan sosial budaya yang berwujud pengetahuan, norma, peraturan, adat istiadat, serta keterampilan-keterampilan hidup yang diwariskan turun temurun. Kearifan lokal di tengah masyarakat memiliki bentuk yang beragam. Sutarso (2012) mengelompokkan beragam bentuk kearifan lokal ke dalam dua kategori, yakni kearifan lokal berwujud dan tidak berwujud. Kearifan lokal berwujud diartikan sebagai kearifan lokal yang dapat dilihat, sedangkan kearifan lokal tidak berwujud merupakan kearifan lokal yang tidak dapat diamati melalui indera pengelihatan. Nilai-nilai kearifan dikelompokkan ke dalam lima kategori oleh Prosser (dalam Sitompul dan Simaremare, 2017), antara lain hubungan dengan Tuhan, hubungan dengan alam, hubungan dengan waktu, berhubungan dengan suatu kegiatan, dan hubungan antar manusia. Pengkategorian ini menunjukkan bahwa kearifan lokal tidak terlepas dari sistem kehidupan manusia. Kearifan lokal senantiasa bersandingan dengan sistem kehidupan dalam masyarakat.

Berdasarkan paparan-paparan tersebut, peneliti terinspirasi untuk melakukan penelitian mengenai sispan nama bunga dalam penamaan orang di kultur masyarakat Jawa. Penelitian yang dilakukan terinspirasi dari tiga penelitian relevan yang sebelumnya pernah dilakukan. Penelitian pertama adalah penelitian Rini, dkk (2018), dengan judul "Pemberian Nama Anak dalam Sudut Pandang Bahasa". Hasil dari penelitian tersebut menyebutkan bahwa orangtua cenderung memberikan nama dengan mencampurkan dua atau lebih bahasa sebagai kombinasi, seperti nama Jawa dan nama dalam agama Islam. Penelitian relevan kedua adalah penelitian yang dilakukan Sahid (2013) dengan judul "Konstruksi Nama Orang Jawa : Studi Kasus Nama-nama Modern di Surakarta". Hasil dari penelitian tersebut mengungkapkan bahwa penamaan orang Jawa memperhatikan tiga hal yaitu bentuk dasar, cara-cara pengubahan nama, dan nama baru sebagai hasil pengubahan. Penelitian 
relevan yang terakhir merupakan penelitian Yosefina Baru (2016) dengan judul "Leksikon Nama Orang Pada Etnis Miyah: Kajian Ekolinguistik". Hasil dari penelitian tersebut mengungkapkan bahwa leksikon yang dominan dipilih dan digunakan sebagai nama orang adalah leksikon yang terkait dengan flora sebanyak 28 jenis, dan nama orang yang terkait dengan leksikon fauna sebanyak 10 jenis. Berdasarkan tiga penelitian relevan tersebut, peneliti menyusun judul penelitian yakni "Makna Kearifan Lokal Nama-nama Bunga dalam Konstruksi Nama pada Masyarakat Kutoarjo, Jawa Tengah". Tujuan dari penelitian diuraikan ke dalam empat hal antara lain, 1) mendeskripsikan salah satu wujud kearifan lokal yang ada pada masyarakat Kutoarjo, 2) mendeskripsikan nilai kearifan lokal, 3) mendeskripsikan makna nama bunga dan penyematan nama bunga dalam konstruksi penaman orang di masyarakat Kutoarjo, dan 4) mengetahui strategi preservasi agar pemberian nama bunga dalam konstruksi penamaan orang di masyarakat Kutoarjo tetap berlangsung secara turun temurun.

\section{METODE PENELITIAN}

Metode penelitian yang diterapkan dalam penelitian adalah penelitian kualitatif. Penelitian kualitatif dilakukan dengan menggunakan metode etnografi. Sudaryanto (2015) mengartikan penelitian kualitatif sebagai penelitian yang berdasarkan fakta atau fenomena yang terjadi di dalam kehidupan keseharian atau secara empiris hidup di tengah penutur-penuturnya. Sedangkan penelitian kualitatif etnografi menurut Spradley (2007) adalah penelitian yang bertujuan untuk memahami suatu pandangan hidup dari sudut pandang penduduk asli. Sumber data dalam penelitian ini adalah tuturan pemaknaan masyarakat mengenai nama-nama bunga, yang disisipkan dalam konstruksi penamaan di dalam kultur masyarakat Jawa. Pemaknaan tersebut diungkapkan dalam proses wawancara yang dilakukan kepada 7 orang narasumber. Wawancara dilakukan dengan mencatat keterangan narasumber tentang pemaknaan nama bunga dalam struktur nama orang di masyarakat Jawa. Penelitian menggunakan teknik analisis data deskriptif, yakni analisis dengan menggunakan kata-kata, kalimat, ataupun paragraf yang dinyatakan dalam bentuk deskriptif (Suprayogo \& Tobroni, 2001). Analisis deskriptif meliputi tiga langkah yaitu proses reduksi data, proses penyajian data, dan penarikan kesimpulan (Sutopo, 2002).

\section{HASIL PENELITIAN DAN PEMBAHASAN}

Objek kajian dalam penelitian ini yaitu kearifan lokal tentang penyematan nama flora/bunga dalam kontsruksi penamaan orang di masyarakat Jawa, melalui sudut pandang ekolinguistik. Dalam penelitian ini, penggalian makna nama bunga pada konstruksi penamaan orang dalam di masyarakat Jawa, ditegaskan bahwa penelitian menggunakan sudut pandang pengertian ekolinguistik alamiah. Penegasan tersebut disebabkan pembahasan dalam penelitian ini mengarah pada pencarian makna nama bunga (flora) dalam konstruksi nama masyarakat Jawa. Hal tersebut sejalan dengan pengertian ekolinguistik alamiah (natural ecolinguistics) yang berfokus pada pencarian makna pemberian nama bunga ke dalam konstruksi nama orang, sebagai bentuk interaksi antara bahasa dengan flora dan fauna. Penelitian dan wawancara dengan narasumber dilakukan di Kutoarjo, Jawa Tengah. Kutoarjo merupakan sebuah kecamatan yang terletak di antara kabupaten Kebumen dan Purworejo.

Peneliti mengumpulkan tiga kategori narasumber. Narasumber kategori pertama adalah narasumber yang terdiri dari 5 orang tua (pasangan suami istri) yang memberi nama bunga di dalam susunan nama anaknya. Narasumber kategori kedua adalah 1 narasumber berusia 52 tahun yang memiliki nama bunga dalam susunan namanya. Narasumber kategori terakhir atau kategori ketiga adalah narasumber yang tediri dari 1 orang muda berusia 22 tahun yang memiliki nama bunga dalam susunan namanya. Narasumber dipilih dan diperoleh secara acak tanpa ada pemilihan dengan mempertimbangkan daerah, usia, pendidikan, atau faktor lainnya. Kategorisasi dilakukan untuk mempermudah dalam penyampaian data narasumber. Setiap narasumber memiliki keterkaitan yaitu memiliki nama bunga dalam konstruksi penamaan, baik di dalam nama anak maupun namanya sendiri. Nama-nama tersebut dirangkum dalam tabel 1 berikut.

Tabel 1. Rekap Narasumber

Narasumber Kategori I (Pasangan Suami Istri)

\begin{tabular}{|c|c|}
\hline \multicolumn{2}{|c|}{ Narasumber Kategori I (Pasangan Suami Istri) } \\
\hline Nama Pasangan Suami Istri (Pasutri) & Nama Anak \\
\hline 1. Pasangan Antok - Shinta & Mawar Zhafira Agni Larasati \\
\hline 2. Pasangan Gigih - Nana & Dafa Ramadhan Wahyu Wijayakusuma \\
\hline 3. Pasangan Priyok - Ratna & Anastasya Mayang Sari \\
\hline 4. Pasangan Rahmat - Tunik & Febriliyana Tunjung \\
\hline 5. Pasangan Agus - Maria & Brigitta Melati Ageng Puspitasari \\
\hline \multicolumn{2}{|c|}{ Nama Narasumber Kategori II (Ibu berusia 52 tahun) } \\
\hline Menur Sulanggani & \\
\hline \multicolumn{2}{|c|}{ Nama Narasumber Kategori III (Orang muda berusia 22 tahun) } \\
\hline 1. Rafael Sasongko Ardiman Puspita & \\
\hline
\end{tabular}

Keterangan : Nama yang bercetak tebal merupakan nama bunga. 
Pemberian dan pemaknaan nama bunga pada konstruksi penamaan orang, merupakan wujud dari kearifan lokal Jawa, khususnya masyarakat Kutoarjo, Jawa Tengah. Kearifan lokal tersebut tergolong pada kearifan lokal yang berwujud pengetahuan dan adat istiadat. Hal tersebut sejalan dengan pendapat Hadayati (2016) yang mengartikan kearifan lokal sebagai tatanan sosial budaya yang berwujud pengetahuan, norma, peraturan, adat istiadat, serta keterampilan-keterampilan hidup yang diwariskan turun temurun. Nama-nama bunga dalam konstruksi penamaan orang di masyarakat Jawa merupakan kearifan lokal yang berwujud pengetahuan. Selain nama-nama bunga yang digunakan dalam konstruksi penamaan, pemaknaan orang tua dan orang yang memberikan atau memiliki nama bunga dalam konstruksi nama, merupakan kearifan lokal yang berwujud adat istiadat. Kearifan lokal tersebut menurut Sutarso (2012), dikategorikan sebagai kearifan lokal yang tidak berwujud. Hal tersebut disebabkan kearifan lokal yang berupa pemberian nama, pemaknaan, yang berwujud pengetahuan tersebut, tidak dapat diamati melalui indera pengelihatan. Sedangkan berdasarkan kategorisasi Prosser (dalam Sitompul dan Simaremare, 2017), pemaknaan nama bunga tergolong dalam kearifan lokal yang memiliki hubungan dengan alam. Berikut merupakan pemaknaan dari masing-masing nama bunga yang disematkan dalam konstruksi penamaan lengkap masyarakat Jawa, berdasarkan wawancara dari 9 narasumber.

\section{Mawar Zhafira Agni Larasati}

Nama lengkap anak perempuan dari pasangan suami istri Antok dan Shinta tersebut memiliki unsur nama bunga, yakni Mawar. Pemberian nama bunga Mawar dimaknai sebagai seorang anak yang diharapkan memiliki sifat mawi arsa, awar-awar ben tawar. Orang tua berharap anaknya senantiasa tulus dalam bertindak, melakukan segala hal tanpa pamrih atau mengharapkan imbalan, dan tidak iri hati terhadap pencapaian atau harta milik orang lain.

\section{Dafa Ramadhan Wahyu Wijayakusuma}

Nama lengkap anak laki-laki dari pasangan suami istri Gigih dan Nana tersebut memiliki unsur nama bunga, yakni Wijayakusuma. Pemberian nama bunga Wijayakusuma dimaknai dalam tiga penggalan yang terdiri dari Wi, Jaya, dan Kusuma. Wi dimaknai sebagai menguasai segala ilmu secara lahir dan batin. Jaya dimaknai sebagai menang tanpa menjatuhkan, dan tangguh tanpa meremehkan. Kusuma berasal dari penggalan tembang Jawa yaitu "Kusuma tedak turning Ratu." yaitu seseorang perlu berbudi luhur sama seperti keluhuran pencipta alam (Tuhan Yang Maha Esa). Wijayakusuma diberikan kepada anak dengan harapan anak tersebut mengenali kapan waktunya untuk unjuk diri atau hanya menunjukkan dirinya di saat yang tepat. Layaknya bunga Wijayakusuma yang mekar pada saat-saat tertentu.

\section{Anastasya Mayang Sari}

Nama lengkap anak perempuan dari pasangan suami istri Priyok dan Ratna tersebut memiliki unsur nama bunga, yakni Mayang. Pemberian nama bunga Mayang dimaknai bahwa biasanya bunga Mayang sering digunakan dalam pernikahan Jawa, yang sering dikenal dengan sebutan Kembar Mayang. Mayang dimaknai sebagai lahirnya sebuah keluarga yang baru. Namun, pemberian nama bunga Mayang di anak merupakan penanda lahirnya keluarga baru. Anak tersebut merupakan penyatu pasangan suami istri yang telah terpisah lama karena pekerjaan yang menuntut mereka untuk hidup di kota yang berbeda. Kelahiran anak tersebut merupakan titik awal pasangan suami istri tersebut menyatu kembali dan sepakat untuk hidup bersamasama di dalam satu kota yang sama

\section{Febriliyana Tunjung}

Nama lengkap anak perempuan dari pasangan suami istri Rahmat dan Tunik tersebut memiliki unsur nama bunga, yakni Tunjung atau yang sering disebut dengan bunga Teratai atau bunga Lotus. Pemberian nama bunga Tunjung dimaknai sebagai seorang anak yang diharapkan menjadi seseorang yang dapat menjadi pribadi yang senantiasa berbuat baik meskipun berada di tempat yang tidak baik atau tidak menyenangkan. Orang tua berharap agar anaknya hidup seperti bunga Tunjung yang membuat kolam keruh menjadi indah karena pesona bunganya. Anak diharapkan menjadi seseorang yang mampu membawa kebahagiaan di tengah-tengah penderitaan, dan kebaikan di tengah keburukan.

\section{Brigitta Melati Ageng Puspitasari}

Nama lengkap anak perempuan dari pasangan suami istri Agus dan Maria tersebut memiliki unsur nama bunga, yakni Melati. Pemberian nama bunga Mawar dimaknai sebagai seorang anak yang diharapkan memiliki sifat rasa melad saka jroning ati, yang memiliki makna harapan seorang tua agar anaknya senantiasa memiliki kebaikan diri dan kebaikan hati, yang ditunjukkan dengan bertindak mengikuti hati nurani. Orang tua mempercayai bahwa setiap tindakan baik muncul jika seseorang mengikuti hati nuraninya.

\section{Menur Sulanggani}


Nama lengkap tersebut memiliki unsur bunga di dalamnya yakni Menur. Pemberian nama bunga Menur dimaknai sebagai seorang anak yang diharapkan menjadi anak yang sederhana. Bunga Menur lekat dengan kesederhanaan hidup. Di masa lampau, terdapat pepatah Jawa yang menyebutkan "Kembang Menur, ditandur ing pinggir sumur, yen wes makmur ojo lali karo sedulur.". Pepatah tersebut mengungkapkan peringatan kepada orang-orang yang telah berhasil untuk tidak lupa kepada orang-orang di sekitarnya. Penyematan nama bunga Menur diharapkan menjadi pengingat kepada orang yang mengembannya untuk senantiasa rendah hati.

\section{Rafael Sasongko Ardiman Puspita}

Nama lengkap tersebut memiliki unsur bunga di dalamnya yakni Puspita. Pemberian nama bunga Puspita dimaknai sebagai orang tua yang berharap agar anak menjadi sosok kreatif dan mampu berkarya menciptakan banyak hal melalui tangannya. Ada pepatah Jawa yang mengemukakan bahwa terkadang seseorang tangane urip atau yang berarti apapun yang dikerjakan, pasti memiliki hasil yang baik. Puspita juga diartikan sebagai harapan orang tua kepada seorang anak agar di kemudian hari anak tersebut dapat berguna bagi orang-orang di sekitarnya.

Pemaknaan nama bunga yang disematkan dalam konstruksi nama lengkap masyarakat Jawa dapat diketahui dengan dibandingkan dengan kategori makna. Kategori makna menurut Leech (1974) terdiri dari makna konseptual, makna asosiatif, dan makna tematik. Makna asosiatif terdiri dari makna konotatif, makna stilistik, makna afektif, makna reflektif, dan makna kolokatif. Pemaknaan nama bunga bagi masyrakat Jawa tergolong ke dalam makna asosiatif. Hal tersebut sejalan dengan pendapat Leech (1974) yang mengungkapkan bahwa makna asosiatif adalah makna yang dimiliki sebuah kata berkenaan dengan adanya hubungan kata itu dengan keadaan di luar bahasa. Makna-makna bunga yang disampaikan oleh masyarakat Jawa yang mengandung makna sifatsifat seseorang, berada di luar lingkup kata bunga yang dinamakan melalui proses nomenklatur.

Pemaknaan dari masing-masing bunga yang disisipkan dalam konstruksi nama lengkap masyarakat Jawa, merupakan kearifan lokal yang dimiliki oleh masyarakat Jawa khususnya masyarakat di kecamatan Kutoarjo. Pemaknaan tersebut dapat ditemukan sama ataupun berbeda di setiap daerah di masyarakat Jawa, tergantung pemaknanya. Dalam penelitian ini, konteks pemaknaan nama bunga dalam susunan nama lengkap merupakan pemaknaan dari masyarakat Kutoarjo. Kearifan lokal pemaknaan bunga masyarakat Kutoarjo memiliki keterkaitan dengan nilai-nilai kebudayaan. Sibarani (dalam Sitompul dan Simamere, 2017) mengungkapkan 16 ragam kearifan lokal yang memiliki nilai budaya. Berdasarkan kategorisasi yang dilakukan oleh Sibarani, pemaknaan nama bunga yang digunakan sebagai susunan pemberian nama di masyarakat Jawa, khususnya kecamatan Kutoarjo, kearifan lokal tergolong dalam kategori nilai kearifan lokal pendidikan.

Nilai kearifan lokal pendidikan dapat diketahui dengan mempelajari tuturan narasumber yang menyebutkan bahwa pemberian nama bunga di setiap nama memiliki tujuan atau maksud untuk mendidik anak agar senantiasa menjadi baik layaknya makna bunga yang tersemat di namanya. Nama bunga juga disematkan sebagai pengingat kepada seorang anak untuk senantiasa berbuat luhur dan tidak berbuat buruk karena mengemban nama bunga yang dimaknai baik. Hal tersebut sesuai dengan pendapat Lono (2006) bahwa nama dapat menjadi alat kontrol sosial, yang mengatur tindakan, norma, perilaku seseorang yang bersifat reflektif. Seluruh narasumber penelitian memiliki persamaan yakni pemberian nama bunga dalam konstruksi nama lengkap di masyarakat Jawa, merupakan doa bagi orang tua bagi keberlangsungan hidup anaknya. Doa-doa baik orang tua atas anaknya disematkan melalui pemberian nama bunga yang dimaknai sebagai hal baik. Hal tersebut sejalan dengan Suranto (1983) yang menyebutkan bahwa penaman di masyarakat Jawa menjadi sebuah wujud panjatan doa orang tua atau keluarga, terhadap jabang bayi yang baru saja dilahirkan dan menjadi bagian dalam keluarga. Penyematan nama bunga di dalam penamaan masyarakat Jawa merupakan kearifan lokal yang rentan terhadap kepunahan. Keberlangsungan penyematan nama bunga di dalam konstruksi nama lengkap masyarakat Jawa, senantiasa utuh dan terjadi turun menurun apabila dilakukan langkah -langkah atau strategi preservasi yang tepat.

Preservasi dalam Kamus Besar Bahasa Indonesia (2016) merupakan kegiatan yang berkaitan dengan pemeliharaan, penjagaan, dan perlindungan. Preservasi dimaksudkan sebagai sebuah tindakan yang berkaitan dengan upaya perlindungan. Tindak preservasi membawa dampak pada keutuhan dan keberlangsungan sebuah budaya, bahasa, kebiasaan, bahkan tindakan seseorang. Dalam konteks penyematan nama bunga dalam konstruksi penamaan orang di masyarakat Jawa, terdapat beberapa strategi preservasi yang dapat dilakukan agar penamaan tersebut tidak hilang dari kultur masyarakat. Peneliti merumuskan tiga strategi preservasi yang dapat dilakukan untuk memelihara penyematan nama bunga dalam konstruksi nama lengkap di masyarakat Jawa. Strategi preservasi pertama yakni setiap orang tua perlu memberikan penjelasan kepada anaknya, terutama ketika orang tua memberikan nama bunga di dalam konstruksi nama lengkap. Setiap orang tua perlu menjelaskan makna di balik nama bunga yang disematkan dalam nama lengkapnya. Hal tersebut dilakukan agar setiap anak yang mengemban nama bunga, memiliki pengetahuan akan makna bunga yang ada di konstruksi namanya. Strategi preservasi yang kedua merupakan preservasi yang dapat dilakukan dalam lingkup pendidikan. 
Preservasi dapat diterapkan pada buku pembelajaran. Secara spesifik preservasi dapat diterapkan pada buku tematik, buku LKS siswa atau narasi pembelajaran. Guru dapat bercerita dalam narasi pembelajaran dengan menyisipkan nama tokoh yang memiliki unsur bunga, seperti Mawar, Menur atau Melati. Setelah memberikan narasi pembelajaran, guru dapat memberikan penjelasan tentang arti nama tokoh yang memiliki nama bunga di dalam cerita. Informasi pemaknaan nama bunga dapat ditambahkan dalam sisipan di buku tematik atau LKS yang dimiliki oleh siswa. Pemaknaan nama bunga dapat ditempatkan dalam satu ruang khusus di sudut buku tematik atau LKS. Strategi preservasi terakhir yang dapat dilakukan adalah mengadakan penelitian untuk merangkum seluruh makna bunga yang dapat digunakan untuk penamaan di kultur masyarakat Jawa, untuk dirangkum ke dalam satu ensiklopedia. Ensiklopedia tersebut berisi kumpulan nama bunga dan makna bunga tersebut ketika disematkan dalam konstruksi penamaan. Ketiga strategi preservasi tersebut dapat dilakukan untuk menjaga keberlangsungan pemberian nama bunga di dalam konstruksi penamaan orang di masyarakat Jawa.

\section{SIMPULAN}

Kajian ekolinguistik alamiah dilakukan untuk menemukan makna nama bunga yang tersemat pada konstruksi penamaan orang di masyarakat Jawa. Berdasarkan penelitian yang telah dilakukan, diperoleh kesimpulan bahwa 1) wujud kearifan lokal berupa adat istiadat berupapenyematan nama bunga dalam nama orang di masyarakat Jawa, 2) nilai kearifan lokal yang terkandung dari penyematan nama bunga dalam nama orang di masyarakat Jawa yaitu nilai pendidikan yang memuat ajaran-ajaran kehidupan, 3) pemaknaan dan pemberian nama bunga dalam penamaan di masyarakat Jawa bertujuan sebagai wujud doa, harapan orang tua akan keberlangsungan hidup anaknya, serta sebagai kontrol sosial anak dalam bertindak, dan 4) strategi preservasi yang dapat dilakukan untuk menjaga keberlangsungan pemberian nama bunga pada penamaan di masyarakat Jawa yakni dengan orang tua memberikan penjelasan kepada anak, menyisipkannya dalam pembelajaran di sekolah, serta menyusun ensiklopedi kumpulan nama bunga yang dapat digunakan dalam penamaan di masyarakat Jawa. Preservasi dapat dilakukan untuk menjaga keberlangsungan pemberian nama bunga di dalam konstruksi penamaan orang di masyarakat Jawa.

\section{DAFTAR PUSTAKA}

Badan Pengembangan dan Pembinaan Bahasa. (2016). Kamus Besar Bahasa Indonesia dalam Jaringan. Diakses dari https://kbbi.kemdikbud.go.id/

Badan Perencana Pembangunan Nasional. (2014). Biodiversity Action Plan for Indonesia. Jakarta: BAPPENAS.

Baru, Yosefin. (2016). Leksikon Nama Orang Pada Etnis Miyah: Kajian Ekolinguistik. .Jurnal Kibas Cendrawasih, 13 (1), 43-50.

Dynash, Juan. (2013). Keanekaragaman Hayati Flora dan Fauna Indonesia. Jakarta: Gramedia.

Hariyani. (2013). Morfologi Tumbuhan Tentang Bunga. Bandung: Andi.

Hariyono, P. (1996). Pemahaman Kontekstual tentang Ilmu Budaya Dasar. Yogyakarta: Kanisius.

Haugen, Einar. (1972). The Ecology of Language. Stanford: Stanford University Press.

Hadayati, D. (2016). Memudarnya Nilai Kearifan Lokal Masyarakat dalam Pengelolaan Sumber Daya Air. Jurnal Kependudukan Indonesia, 11 (1), 39-48.

Joko Sutarso. (2012). Menggagas pariwisata berbasis Budaya dan Kearifan Lokal, Menggagas Pencitraan Berbasis Kearifan Lokal. Jurnal Pariwisata Indonesia, 4 (2), 505-515.

Leech, Geoffrey. (1974). Semantics: The Study of Meaning. Ohio: Penguin.

Rini, Nur., Sri Rahayu Zees., Pandiya. (2018). Pemberian Nama Anak dalam Sudut Pandang Bahasa. Jurnal Epigram, 15 (2), 145-153.

Simatupang, L.L. (2006). Nama Anak - Aristokratisme dan Keberatan Nama. Harian Umum Kompas: Edisi 23 April 2006, 34

Sitompul, Eden A. \& Simaremare, J.A., (2017). Analisis Fungsi, Nilai Budaya, dan Kearifan Lokal dalam Film Sinamotkarya Sineas Muda Medan: Kajian Antropolinguistik. Jurnal Suluh Pendidikan FKIP-UHN, 4 (2), 24-27.

Spradley, J. P. (2007). Metode Etnografi. Yogyakarta: Tiara Wacana.

Stibbe, A. (2015). Ecolinguistics: Language, Ecology, and The Story We Live Vy. New York.

Sudaryanto. (2015). Metode dan Teknik Analisis Bahasa. Yogyakarta: Duta Wacana University.

Suprayogo, Imam \& Tobroni. (2001). Metodologi Penelitian Pendidikan. Bandung: Remaja Rosdakarya.

Suranto, A. (1983). Studi tentang sistem nama-nama Jawa. Surakarta: Krida Aksara.

Widodo, Sahid Teguh. (2013). Konstruksi Nama Orang Jawa: Studi Kasus Nama-nama Modern di Surakarta. Jurnal Humaniora, 25 (1), 82-91. 